\title{
Non-classical Intentionality: An Existential View
}

\author{
VLADIMIR CHERNUS \\ Faculty of Humanities at National Research University - Higher School of Economics, 20 Myasnitskaya Street, Moscow, 101000, Russia \\ Email:vlchernus@mail.ru
}

\begin{abstract}
This paper compares the ideas of intentionality and 'pure Self' in the phenomenological and existential traditions. The purpose of the research is to compare and identify the meaning of these categories that is different from the phenomenological approach. While phenomenology was conceived as an epistemological program, the existential view represented in the paper by Nikolai Berdyaev shows the negative ontological consequences to which it leads. For example, the idea of intentionality (the direction of consciousness toward an object) can lead to the elimination of subject from the life picture of the world, whereas the idea of a 'transcendental Self' leads to the justification of the lack of content in consciousness. Therefore, there is a conflict between these philosophical approaches. The topicality of the problem under study is due to identification of details and specific features of this conflict. The goal of phenomenology is purification of consciousness from subjective premises for achieving objective cognition. The goal of existentialism is the formation of existence of the subject, the actualization of his/her immanent freedom. Thus, the existential approach broadens the ideas on the nature of the consciousness orientation, which can be directed not only toward the phenomenal world, but also to the transcendental one. The scientific value of this study is due to the reconstruction of the existential approach concerning the issue of the direction of consciousness and the 'pure Self' using the example of Berdyaev's philosophy, as well as the possibility of creating 'ontology of consciousness' based on his philosophy.

The article is based on the method of theoretical reconstruction and conceptual analysis of the arguments put forward by E. Husserl and N. A. Berdyaev, as well as numerous researchers of their work. The methodological basis of this work is a philosophical reconstruction and a comparative approach. The scientific significance of the research is justifying that the existential approach to 'intentionality' does not deny the phenomenological approach but enlarge it adding ontological content in this notion.
\end{abstract}

Keywords: phenomenology, intentionality, Husserl, Berdyaev, structure of the intentional act

\section{INTRODUCTION}

In modern discourse, the existence of an integrated and indivisible 'Self' as the quintessence of consciousness is brought into question. The causes of human behaviour are associated not with the freedom of choice, but with the biological processes occurring inside the organism. 
Human actions may be deterministic or random, but not free (Harari 2019: 334). Therefore, people can be influenced from the outside, can be forced to make this or that decision. Now the technologies are designed that can influence the freedom of choice. The philosophical problem lies in the fact that if it becomes possible to subjugate human behaviour from the outside, then the subject endowed with free will is going to be eliminated from the life picture of the world.

In the present study, a hypothesis is set forward that one of the possible reasons for the development of such a negative scenario is the phenomenological paradigm, which is accepted by default in the philosophical and scientific community.

In phenomenology, we will be interested in the epistemological program, its ontological consequences, the intentional structure of consciousness, and the idea of a 'pure Self'. Using the existential tradition represented by N. Berdyaev, a different ontological meaning will be demonstrated, which relates to the idea of intentionality and 'pure Self' as possible existential ways out of the ontological impasse of phenomenology.

Nowadays the literature about phenomenology is well-developed. In this regard, significant are the articles aimed at the formation of a holistic view of the intentionality, because having analysed the general idea of phenomenology, we can proceed to the particular topics of intentionality and the 'philosophy of consciousness'. It includes articles of such authors as C. Van Mazijk (Van Mazijk 2019), M. Doyon and T. Breyer (Doyon, Breyer 2020), H. B. Schmid (Schmid 2018) and C. Liu (Liu 2019). From the articles devoted to the phenomenolgy and content the article of K. Laasik (Laasik 2019) should be noted. From studies on the phenomenology and ontology, note the article of S. Crowell (Crowell 2019). The comparative analysis of the category of 'intentionality' by E. Husserl and S. L. Frank, conducted by G. E. Alyaev, is of interest. The Transcendental Reduction is considered in the works of S. Vincini (Vincini 2020). J. Webber wrote about Sartre's critique of Husserl (Webber 2020). The problem of Noema and Noesis in phenomenology is the subject of W. Krysztofiak's research (Krysztofiak 2020). The article by T. Arnold represents the interests (Arnold 2020) as it arises the problem of object(s) of phenomenology.

\section{THE INTENTIONAL NATURE OF CONSCIOUSNESS IN THE PHENOMENOLOGICAL TRADITION}

According to Husserl, the main ability of consciousness is to produce intentional acts, that is, to direct itself towards an object (Husserl 1939: 699), which can be both real and ideal (both a specific state of affairs and essence) (Husserl 2001: 384-385). The task of phenomenology is to purify consciousness, to get rid of the psychological premises of consciousness through 'phenomenological reduction' (to take the surrounding world off the table), to cognize things as they are. The motto of phenomenology, Zu den Sachen, means both 'to things as they are in themselves' and 'let us study what matters' (van Manen 1990: 184). The analysis of the intentional act helps to cognize the object (thing) as it is.

In his writings, Husserl almost never uses the concept of Objekt, preferring the concept of Gegenstand ('thing'). In later works, the philosopher, speaking about the direction of consciousness toward things, uses the term Gegenstände. It seems that the concept of 'object' appears in the English-language tradition of studying phenomenology, in which there is no verbal equivalent to the term Gegenstand.

In the lecture course 'The Idea of Phenomenology' (Husserl 2008: 55), besides the concept of Gegenständlichkeit (thingness) or Gegenständlichkeiten (thingnesses), Husserl uses the terms Gegenstand and Objekt. This is explained by terminological differences: for Husserl, a 'thing' (or 
'thingness') literally means 'that which stands opposite', that is, a thing that is constituted by consciousness, while 'object' is transcendental, that is, exists outside of consciousness.

J. Kochan (2011) writes about the phenomenological approach in the philosophy of consciousness, paying attention to the fact that Husserl understood experience in terms of consciousness, downplaying individual experience, turning it into a collective one. Thus, it becomes possible for consciousness to perceive a pure, objective phenomenon. Consequently, there is a danger of understanding phenomenology as anti-realism and idealism.

According to Husserl, the essence of the phenomenal world is revealed by the method of 'phenomenological reduction' - by equally setting aside all preconditioned judgments about a thing, toward which consciousness is directed, and the empirical world as external to consciousness. The philosopher differentiates between two layers in human consciousness - the 'empirical' and 'psychological' ones: it is necessary to clear the consciousness from the psychological layer, which is the individual 'Self', because only the purified consciousness is capable of genuine intentionality, that is, pure premise-free contemplation.

Husserl's goals are strictly epistemological. He considered experience as the main source of knowledge (Racher, Robinson 2003; Ricci 2010). The task of phenomenology is a rigorous and objective study of things, how they manifest themselves, which should lead to understanding of the nature of consciousness and experience (Valle, King, Halling 1989). To reveal the essence of phenomena free of subjective experience, Husserl invented a 'phenomenological reduction'.

\section{ONTOLOGICAL CONSEQUENCES OF PHENOMENOLOGY AS AN EPISTEMOLOGICAL PARADIGM}

Since the publication of 'Logical Investigations', phenomenology has undergone some transformations. For example, P. Ricoeur called it the story of heresies (Riccoeur 1953: 836), and there are as many styles in phenomenology as there are phenomenologists (Spiegelberg 1982; Spiegelberg 1960).

The successors of Husserl leave aside not only opinions about the existence of the external world, but also the subject him/herself (Richir 2000: 27; Richir 2000; Detistova 2012). For example, M. Richir asserts that the description of a phenomenon should not be based on the experience of a phenomenological subject, since in phenomenology the non-subjective origin of the phenomenon itself is postulated (Richir 1997). Hence the hypothesis is formulated that phenomenology, being consistently developed, will lead to the denial, first, of the 'psychological Self' (the psychological layer of consciousness), then consciousness itself and, finally, the value of the epistemological subject in the process of cognition.

Phenomenology can become the philosophical justification of the phenomenal world as an exceptional space of objects, where each epistemological subject is perceived as an object. In such a world, subjects enter only into object relations with each other and, directing their consciousness to the object, objectify themselves, that is, turn into objects. In such a world, intentionality itself from a predicate of subject becomes a carrier of subjectivity. The subject becomes an 'indending object'.

Why should intentionality be a privilege exclusively of a subject? Initially, there was a subject and its predicate, intentionality. In the process of development of the intentionality idea, the subject turns into an object (objective cognition of the phenomenal world takes place), while the predicate of intentionality turns into a carrier of subjectness. However, to possess a feature of subjectness and to be a subject is not the same thing: an object can possess only individual properties, but not subjective ones. So subjectness becomes individuality. 
The consent to 'objectification' of one's 'Self' by other consciousnesses and the 'objectification' of other people is the reason for the transformation of the 'life world' into the world of objects: 'Self perceives the other as an object and agrees that the other perceives me as an object. This vicious circle of 'objectification' leads to a collective suicide of subjectness; individuality occupies its place, which is only an attribute of the object.

As a counterargument to the above, it can be pointed out that in phenomenology there is a problem of intersubjectivity, which is connected with the recognition of the existence of another 'Self', other consciousnesses, other subjects of individual experience that are equal to my own.

Husserl borrowed the idea of intersubjectivity from the transcendental philosophy of Rene Descartes, Immanuel Kant and Johann Gottlieb Fichte, recognizing the presence of many subjects inherent in the structure of consciousness. Thus, he equated transcendental subjectivity with transcendental intersubjectivity. According to Husserl, it is possible to think of the other not only as an object of the phenomenal world, but also as a subject who perceives the phenomenal world as a 'Self, and me in it, as the other. The presence of another in the phenomenal world determines the self-awareness of the transcendental-phenomenological 'Self. The subject recognizes him/herself in the other and the other, in him/herself ('recognition' is revealed by Husserl in the concepts of 'intentionality', 'analogizing appresentation' or associative awareness of the similarities of 'my' body and the body of the other), and this leads to the formation of a 'life world' in which the communication acts are performed requiring mutual understanding and self-identification of their participants. According to Husserl, intersubjectivity does not arise in these acts, but precedes them; it is thanks to it that these acts are possible; it serves as a guarantee that 'subjective realities' are comprehensible: we are able to understand the goals, meanings and intentions (at least some) of other people; the world of 'my' consciousness is the common space of humanity.

This space is a transcendental field of consciousness, which Husserl calls the life world (Lebenswelt). The life world is an object of direct experience (intuition), which is a point of departure of phenomenological research.

\section{THE INTENTIONAL NATURE OF CONSCIOUSNESS: AN EXISTENTIAL VIEW}

The philosophy of N. A. Berdyaev agrees that 'by default' consciousness is directed at objects, but expands its limits proposing a different view of intentionality. The philosopher calls this process 'objectification', which, with some reservations, is like intentionality. By 'objectification' we mean the process of perceiving everything that consciousness is directed to in the phenomenal world as an object.

Consciousness directs itself to different objects: it tries to rise to super-consciousness (philosophy) or to the subconscious (Freudism). Consciousness tries to root a person in the space of his/her existence. Being present in the phenomenal world, consciousness, through intentional acts, tries to root a person in the phenomenal world, but in practice such rooting means the suicide of the 'Self-subject and its transformation into an 'intending' individual object. The reason for this transformation is that consciousness gives meaning to the object that it directs itself to and transfers power over itself to it. Therefore, the main activity within the framework of the phenomenal world is the competition of objects for the attention of consciousness. As a result, consciousness loses free will; this is mentioned often in modern philosophy. However, the reason for the loss of free will lies in the very nature of the intentional act. 


\section{EXISTENTIAL WAY OUT OF THE ONTOLOGICAL IMPASSE OF PHENOMENOLOGY}

Berdyaev has a remarkable expression: false attitudes of consciousness are a source of human slavery (Berdyaev 1995: 382). This can be interpreted as 'objectified intentionality': the direction toward an object, and not on a subject, which in its limit can cause the transformation of a person into an 'intending object'.

According to Berdyaev, 'one of the greatest and unjustified prejudices of epistemology lies in the fact that cognition is opposed by an object that is outside it, an object that must be reflected and expressed in cognition' (Berdyaev 2003: 26).

Berdyaev was familiar with Husserl's concept and spoke rather skeptically about it: 'No matter how hard Kochan and Husserl try to endow cognition with a character transcendental to a person and free cognition from any anthropologism, these attempts will always give the impression of raising oneself by the hair. Man precedes philosophy, man is the premise of any philosophical cognition' (Berdyaev 2004b: 48).

Berdyaev thought that, by having gotten rid of the psychological layer of 'Self', Husserl arrived at a rational metaphysics with the idea of cognition through the concept: 'In order to cognize a thing according to a phenomenological attitude, one must totally renounce the human, come into a state of perfect passivity, enable the thing itself, the entity itself to speak inside me. Man must cease to exist in the cognition act. Cognition takes place in the realm of ideal logical being, and not in the human realm' (Berdyaev 2004c: 39).

To overcome the phenomenological understanding of intentionality, consciousness needs to learn to perceive not only objects, but also subjects.

It is difficult to rationally explain the process of perception of a subject, and how it will differ from the perception of an object. When directing consciousness towards a person, it is necessary to look at the center of the existential 'Self, which is located behind the facade of the 'psychological Self. While in phenomenological reduction it is necessary to purify the consciousness from preconditioned subjective judgments about an object, in Berdyaev's philosophy, everything needs to be done in the opposite way: consciousness should be cleaned of any object ideas about a subject. The gaze of consciousness should be directed to the existential center of the subject while taking aside the object ideas about it. The ethical component is that each person should be treated as a subject.

\section{'PURE SELF' IN THE FRAMEWORK OF PHENOMENOLOGY}

In the work 'Ideas for Pure Phenomenology and Phenomenological Philosophy' (Husserl 2009: 489), Husserl, being influenced by neo-Kantians, proposes the idea of a 'pure Self' or 'pure consciousness', which can be arrived at by the method of 'transcendental reduction'. For Husserl, consciousness is always connected with the life experience of the world. And this shows the correlation of subject and object in the experience. It is in this experience that the subject is constituted as a subject through his/her active involvement in the world. Husserl writes: So much is clear from the outset, that after carrying [the transcendental] reduction through, we shall never stumble across the pure Ego as an experience among others within the flux of manifold experiences which survives [the transcendental reduction]; nor shall we meet it as a constitutive bit of experience appearing with the experience of which it is an integral part and again disappearing. The Ego appears to be permanently, even necessarily, there, and this permanence is obviously not that of a stolid unshifting experience, of a 'fixed idea' ... In principle, at any rate, every cogitatio can change ... But in contrast, the pure Ego appears to be necessary in principle, and as that 
which remains absolutely self-identical in all actual and possible changes of experience, it can in no sense be reckoned as a real part or phrase of the experiences themselves (Husserl 2009: 235). I. Miller notes (Miller 1986: 536) that, in this passage, Husserl moves away from his previous position regarding the 'pure Self'. Now he believes that it can be reached. According to Miller, Husserl changed his opinion about the possibility of comprehending the 'pure Self' - this is the desire to combine the experience of changing consciousness with phenomenological theory.

In the later phenomenology of Husserl, 'Pure Self' can be considered as an intentional agent, as the central core of consciousness, the direct carrier of intentionality. Spielberg in his paper (Spielberg 1982: 74) points out that existentialists, in particular, Sartre, borrow Husserl's method of transcendental reduction; however, at the same time, do not come to a 'pure Self', but to a stream of impersonal consciousness, which actually denies the very idea of existence.

Husserl's 'pure Self' is, on one hand, the starting point of intentionality, and, on the other, the ultimate goal of the epistemological system, being its central core. Husserl's 'Pure Self' has no content, because if it had it, then it would be neither whole nor pure. Even if we come to it through 'transcendental reduction', we will come to a formal abstraction.

For Husserl, the 'transcendental Self' is a solution to the problem of intersubjectivity. M. James (James 1964: 57) writes that, for Husserl, the idea of 'transcendental Self' is one of the categories in the study of the transcendental field of phenomena (experiencing the world as such), being a noetic field of phenomenological research. In Husserl's idealistic interpretation, the phenomenal field is interpreted as the field of pure transcendental subjectivity - the field of 'world as meaning', which is effortlessly constituted by an active meaning-generating operation (Sinngebung), which is the very definition of 'pure consciousness'. This transcendental field of consciousness is neither 'mine', nor 'yours', nor 'ours'. The problem of intersubjectivity is solved by 'transcendental reduction', thanks to which we achieve a pure, anonymous, impersonal consciousness below the empirical and historical level of individual experience. This is a region of transcendental subjectivity, which includes the laws of intentional constituting.

\section{'THE TRUE SELF': AN EXISTENTIAL VIEW}

Within the framework of Berdyaev's philosophy, the reasons for the slavery of the 'psychological Self' will be that consciousness, as in phenomenology, has two layers: a 'psychological Self' and a 'potentially true Self'. Consciousness itself, by its nature, is potentiality, which strives for its actualization, it is a form that seeks to find its content. In this case, the 'potentially true Self' will be a subject, while the 'psychological Self', a predicate. The 'Psychological Self' strives to become a subject from the predicate and find its content, whereas something in the phenomenal world should become its content. Hence people's desire to cognize things, on the one hand, and to possess them, on the other. However, instead of becoming a subject, the 'psychological Self' falls into the trap of the world of objects, becoming its slave, and ultimately an 'intending object'.

Husserl's 'transcendental Self' has no content, being the starting point of intentionality; whereas, just the other way round, Berdyaev's 'potentially true Self' acquires its content as it actualizes. The issue of the content of the 'true Self' is the subject of a separate study, but here let us just note that this content is freedom, understood as the existential space of subjects. As the consciousness gains its 'true Self', the starting point and subject of intentionality will change from the 'psychological Self' to the true Self, from the world of objects to the transcendental world, to God, who is revealed to the 'true Self' as an absolute subject. 


\section{EXISTENTIAL CHANGE OF THE SUBJECT OF AN INTENTIONAL ACT}

Berdyaev believes that the person is religious at the core; if he/she ceases to worship God, then he/she will worship things (Berdyaev 1998: 91; Berdyaev 2004a: 281), i.e. he/she will give value to the thing on which his/her consciousness is directed.

As soon as consciousness renounces the divine Logos and transcendental principles, then, believing that it has become free, it transfers quasi-religious feelings to something in the world of objects, while losing its 'free will'. The only question is which of the objects should be assigned a value. In our opinion, the main activity in the modern world is the competition of the objects of worship.

According to Berdyaev, philosophy should begin not with a question about the object, but with disappointment in the object. And this disappointment is a moment of the person's spiritual experience. The person experiences despair because of meaninglessness of the world of objects. And this despair is the first step to change the subject of the direction of one's consciousness. At the first stage, the person experiences loneliness. Loneliness is a disappointment in consciousness' endowing an object with a value, since an object cannot become for me either meaning or another 'you'. At this moment, self-consciousness of the person as a subject in the world of objects is born. Copleston (Copleston 1984: 22) writes precisely about this when speaking of existentialism as a philosophy that affirms a free human being who struggles with totality, collectivity and depersonalization.

Berdyaev's views on the nature of the direction of consciousness were expressed in the critique of phenomenology from the positions of religious existentialism. The existential experience of despair, loneliness, meaninglessness and absurdity becomes a catalyst for changing the direction of consciousness. For such a consciousness, the noumenal world, where God is revealed as a subject, becomes perceptible. Such subjective cognition will be absolutely opposite to the cognition of the phenomenal world. Consciousness aspires to become the subject on which it is directed. If consciousness is directed to the world of objects, then it becomes an object; there deontologization and desubjectivization take place and, as a result, transform into an 'intending object'; if consciousness changes the object of its orientation from object to subject, then the consciousness acquires its 'true Self'.

\section{CONCLUSIONS}

In the foundation of phenomenology there is a platonic idea of the possibility of attaining objective knowledge. The critique of phenomenology from the existential standpoint can be considered as a more fundamental critique of Platonic tradition. In modern philosophy, the value of this ancient tradition is questioned. The work 'Black Swan' (Taleb 2009) is a prime example of this.

Husserl and Berdyaev are in solidarity over the idea of the intentional nature of consciousness; both strive to get remove the psychological layer of consciousness. However, they draw completely different conclusions from this. For Husserl, this is an epistemological program, and for Berdyaev, an ontological program. Berdyaev reveals catastrophic ontological consequences of the phenomenological epistemological program, showing it, on the one hand, as a way of turning consciousness into a slave of the world of objects, transformation into an intending object (the idea of intentionality), and on the other, as the loss of content of consciousness ('transcendental Self' as the starting point of intentionality). 
Our correspondence polemic between phenomenology and religious existentialism is a polemic about values. Which value is greater: The 'I-subject' or the cognition of the phenomenal world? From an existential point of view, the striving of consciousness for pure and objective cognition free from subjective layers is the striving of the 'psychological Self' to find its content, although it does not realize this, postulating strictly scientific goals. On the other hand, a consistently implemented phenomenological paradigm will result in the elimination of the subject from the life picture of the world.

Berdyaev seeks to solve both problems: to change the object of consciousness orientation, as well as to actualize the 'potentially true Self', to fill it with content. Moreover, the actualization of the 'potentially true Self' and its transformation into the 'true Self' consists of changing the subject of its orientation. As the 'true Self' actualizes, consciousness acquires its content, which is freedom, the subject of Berdyaev's ontology. And so ontology becomes the content of consciousness (Sartre 1943).

\section{GRATITUDES}

The author would like to express gratitude to his scientific adviser Porus Vladimir Natanovich for his advice during writing of this paper, as well as to the 'House of A. F. Losev' Library (Moscow, 33 Arbat Street) for access to their literature.

Received 11 June 2020

Accepted 7 September 2020

\section{References}

1. Alyaev, G. E. 2012. On the Philosophical Method S. L. Frank (Phenomenology not according to Husserl). The Philosophy of Russia in the First Half of the XX Century. Semyon Ludwigovich Frank. Moscow: AST (in Russian).

2. Arnold, T. 2020. 'The Object(s) of Phenomenology', Husserl Studies 36: 105-122.

3. Berdyaev, N. A. 1998. Spiritual Crisis of the Russian Intelligentsia. A Sick Russia. Moscow: Kanon+ (in Russian).

4. Berdyaev, N. A. 2003. Meaning of Creativity. Moscow, Russia: AST (in Russian).

5. Berdyaev, N. A. 2004a. The Soul of Russia. Moscow, Russia: AST (in Russian).

6. Berdyaev, N. A. 2004b. Me and the World of Objects. Moscow: AST (in Russian).

7. Berdyaev, N. A. 2004c. Destiny of Man. Experience of Paradoxical Ethics. Moscow: AST (in Russian).

8. Copleston, F. C. 1948. 'Existentialism', Philosophy 23(84): 19-37.

9. Crowell, S. 2019. 'Phenomenology, Ontology, Nihilism: Løgstrup, Levinas, and the Limits of Philosophical Anthropology', Quarterly Journal of Mechanics and Applied Mathematics 72: 16-37.

10. Detistova, A. S. 2012. 'Rishir's Phenomenological Project: Fantasy as Measurement of the Phenomenological', Questions on Philosophy 6. Available at: https://vphil.ru/index.php?id=558\&option=com_content\&task=view

11. Doyon, M.; Breyer, T. 2020. 'Time and Intentionality', Phenomenology and the Cognitive Sciences (in print).

12. Harari, Y. N. 2019. Homo Deus: A Brief History of the Future. Moscow: Sinbad (in Russian).

13. Husserl, E. 1939. 'Phenomenology', in The Encyclopaedia Britannica. 14th edn. Chicago.

14. Husserl, E. 2001. Logical Research. Trans. V. I. Molchanov. Moscow: Dom Intellektual'noi knigi (in Russian).

15. Husserl, E. 2008. The Idea of Phenomenology. Five Lectures. Trans. N. A. Artyomenko. Saint Petersburg: Gumanitarnaya akademiya (in Russian).

16. Husserl, E. 2009. Ideas for Pure Phenomenology and Phenomenological Philosophy. Trans. A. V. Mikhailova. Moscow: Akademicheskiy proekt.

17. James, M. 1964. 'Transcendental Phenomenology and Existentialism', Philosophy and Phenomenological Research 25(1): 52-63. Available at: https://philpapers.org/rec/EDITPA

18. Krysztofiak, W. 2020. 'Noema and Noesis. Part II: Functions of Noematic Synthesis', Axiomathes 30: 269-287.

19. Laasik, K. 2019. 'Phenomenology and Perceptual Content', Southern Journal of Philosophy 57: 402-427.

20. Liu, C. 2019. 'Prinzipien und Grundlagen der Wahrnehmungsauffassung bei Husserl', Husserl Studies 35: 149-176. 
21. Manen, M. van. 1990. Researching Lived Experience: Human Science for an Action Sensitive Pedagogy. Ontario: Althouse Press.

22. Mazijk, C. van. 2019. 'Husserl, Impure Intentionalism, and Sensory Awareness', Phenomenology and the Cognitive Sciences 18: 333-351.

23. Miller, I. 1986. 'Husserl and Sartre on the Self', The Monist 69(4): 534-545.

24. Racher, F.; Robinson, S. 2003. 'Are Phenomenology and Postpostivism Strange Bedfellows?', Western Journal of Nursing Research 25(5): 464-481.

25. Ricci, G. R. 2010. 'Husserl's Assistants: Phenomenology Reconstituted', History of Europeans Ideas 419-426.

26. Richir, M. 1997. 'Doute hyperbolique et "machiavélisme": l'institution du sujet modern chez Descartes', Archives de la Philosophie 60 (Janvier-Mars), Cahier 1.

27. Richir, M. 2000. Phénoménologie en esquisses. Grenoble: Jérôme Millon.

28. Ricoeur, P. 1953. 'Sur la phénoménologie', Esprit 21: 821-839.

29. Sartre, J.-P. 1943. L'être et le néant: Essai sur lontologie phénoménologique (Being and Nothingness. An Essay on Phenomenological Ontology). Paris: Gallimard.

30. Schmid, H. B. 2018. 'The Subject of "We Intend", Phenomenology and the Cognitive Sciences 17: $231-243$.

31. Spiegelberg, H. 1960. 'Husserl's Phenomenology and Existentialism', The Journal of Philosophy 57(2): 62-74.

32. Spiegelberg, H. 1982. The Phenomenological Movement. Dordrecht: Martinus Nijhoff.

33. Taleb, N. N. 2009. Black Swan: Under the Sign of Unpredictability. Trans. V. Sonkin, A. Berdichevsky, M. Kostionova, O. Popov, M. Tyunkin. Moscow: Kolibri (in Russian).

34. Valle, R. S.; King, M.; Halling, S. 1989. 'An Introduction to Existential-phenomenological Thought in Psychology', in Existential-phenomenological Perspectives in Psychology. Exploring the Breadth of Human Experience, eds. R. S. Valle and S. Halling. New York: Plenum Press, 3-16.

35. Vincini, S. 2020. 'The Epistemological Contribution of the Transcendental Reduction', Husserl Studies (in print).

36. Webber, J. 2020. 'Sartre's Critique of Husserl', British Journal for the History of Philosophy 28: 155-176.

\title{
Neklasikinis intencionalumas: egzistencinis požiūris
}

\begin{abstract}
Santrauka
Straipsnyje lyginamos intencionalumo ir „grynojo Aš" idejjos fenomenologinèje ir egzistencinèje tradicijose. Tyrimo tikslas - palyginti ir nustatyti šių kategorijų prasmę, kuri skiriasi nuo įprastos fenomenologineje prieigoje. Nors fenomenologija suprantama kaip epistemologinè programa, Nikolajaus Berdiajevo tekste išdèstytas egzistencinis požiūris parodo jos negatyvias ontologines pasekmes. Pavyzdžiui, intencionalumo idẻja (sąmonès nukreiptumas ị objektą) gali pašalinti subjektą iš gyvenamojo pasaulio vaizdo, o „transcendentalinio Aš idejja veda ị sąmonès turinio stokos pateisinimą. Todèl tarp šių filosofinių prieigų esama konflikto. Nagrinejjama problema tampa aktuali identifikuojant konflikto detales ir specifiką. Fenomenologijos tikslas - sąmonès apvalymas nuo subjektyvių prielaidų siekiant objektyvaus pažinimo. Egzistencializmo tikslas - subjekto egzistencijos formavimas, jo / jos vidinės laisvės aktualizacija. Tad egzistencinè prieiga praplečia šias idèjas apie sąmonès orientacijos pobūdị: ji gali būti nukreipta ne tik ị fenomenų pasaulị, bet ir ị transcendentinị. Mokslinè šios studijos vertè glūdi egzistencinès prieigos rekonstravime susitelkiant $\mathfrak{i}$ sąmonès nukreiptumo ir "grynojo Aš problematiką, remiantis N. Berdiajevo filosofijos pavyzdžiu, taip pat tai - galimybė sukurti jo filosofija grịstą „sąmonès ontologiją“. Straipsnis remiasi teorinès rekonstrukcijos metodu ir Edmundo Husserlio, N. Berdiajevo, taip pat daugelio kitu jų darbų tyrinètojų argumentų koncepcine analize. Metodologinis šio darbo pagrindas yra filosofinè rekonstrukcija ir lyginamoji prieiga. Moksliné tyrimo reikšmé - parodyti, kad egzistencine ,intencionalumo“ traktuotė ne neigia fenomenologinę, o ją praplečia, papildydama ontologiniu turiniu.
\end{abstract}

Raktažodžiai: fenomenologija, intencionalumas, Husserlis, Berdiajevas, intencionalaus akto struktūra 